\title{
Preface: a collective book project - the last chance? Voluntary actors in an ecological and economic transition
}

The world has, on some key dimensions, made extraordinary progress since the end of World War II: output per head has quadrupled; poverty, in terms of incomes, has been dramatically reduced; life expectancy has increased by around 30 years. However, the extraordinary growth has come at colossal environmental cost and the world is now in a deeply dangerous position with a very narrow window for action. Our biodiversity has been brutally damaged, our oceans have been fundamentally altered and marine life is in great danger, our forests have been ravaged, our air and water have been profoundly polluted, and our climate is gravely threatened in ways that could cause immense harm to lives and livelihoods across the world, lasting for centuries. Time is short. If we fail to act decisively in this decade, the damage to our climate, oceans and biodiversity is likely to be irreversible. This is our last chance to save the planet as we know it.

This book is about and by those who have not only understood those threats but become witness to them, and confronted them, often at great costs to themselves. The forces against them are systemic. And the individuals or organizations they have to take on are powerful, and often ruthless and malevolent. The most celebrated pronouncement in economics - Adam Smith's on the "invisible hand": "By pursuing his own interest he frequently promotes that of society more effectually than when he really intends to promote it" (Smith, 1776) - today sounds desperately outdated. Instead of a competitive market, where providers meet consumers' demands, we have at the core of the economy a nexus of dominant firms - private oligopolistic in Western countries, state-owned or state-controlled in China, cronyist in Russia, Iran and other developing countries - pursuing their own goals of profit and power, mostly indifferent to the welfare of the people, particularly inimical to their health and the environment within which they live. They are feeding the exorbitant financial returns expected by shareholders, or by any sort of people in control, by systematically destroying the natural capital - biodiversity, air, water, soil, climate - without which life on earth is doomed to collapse. 
The book is also about and by those who have seen ways forward to a much better development path for human well-being, security and dignity. We can raise living standards and fight poverty across the world at the same time as creating a much safer and more attractive environment. Their momentum is building. The old polluting forces are somewhat weakening. But our future is in the balance. This book is an attempt to share their voices, vision and hope and thus help to tilt the balance their way.

The evidence on the scale and urgency of the threats is overwhelming. There should be no doubt that we are facing global systems challenges across multiple dimensions crucial to our well-being. There has been a flood of scientific warnings, illustrated in the following examples.

The 2019 Aqueduct Water Risk Atlas (published by the Water Resources Institute) identifies 17 countries, which are home to a quarter of the world's population, facing "extremely high water stress, close to day zero conditions when the taps run dry" (Hofste, Reig and Schleifer, 2019). India and Pakistan are among them. Countries and regions - the Yellow River basin, for instance - depending on dwindling Himalayan or Andean glaciers for their water, are on the edge, as are the Southwestern United States, Mexico and Central America, as well as countries around the Mediterranean Sea.

This severe water predicament is closely connected to global warming. 'The Intergovernmental Panel on Climate Change (IPCC) in 2018, when comparing $1.5^{\circ} \mathrm{C}$ and $2^{\circ} \mathrm{C}$ (increases in global mean temperature above pre-industrial levels), highlighted that the proportion of the global population exposed to severe heat at least once every five years is more than 2.5 times greater (Dosio et al., 2018) and the proportion of vertebrate and plant species that lose at least half of their bioclimatic range is double (Warren et al., 2018). There is strong evidence that exceeding $2^{\circ} \mathrm{C}$ will result in large biomes on Earth collapsing, such as coral reefs and tropical forests, and that going even beyond implies that "warming could activate important tipping elements, raising the temperature further to activate other tipping elements in a domino-like cascade that could take the Earth System to even higher temperatures" (Steffen et al., 2018, p. 8254). This describes a road to unbearable conditions of life on Earth: "In the absence of migration, one third of the global population is projected to experience a mean annual temperature greater than $29^{\circ} \mathrm{C}$, currently found in only $0.8 \%$ of the Earth's land surface, mostly concentrated in the Sahara" (Xu et al., 2020, p. 11350). Giant redwoods in Sequoia National Park, California, are already having enough. They were supposed to live for another 500 to 1000 years. The combination of drought stress, fire damage and overall warming, have made them vulnerable, for the first time as far back as we can know, to bark beetles infestations. "That's not how giant sequoias die", laments Dr Christy Brigham, chief biologist of Sequoia and King's Canyon National Parks (Childs, 2020). A stern health warning was recently formulated by the 
2019 Lancet Countdown on health and climate change: "A business as usual trajectory will result in a fundamentally altered world. The life of every child born today will be profoundly affected by climate change" (Watts et al., 2019).

The combination of climate change and loss of biodiversity will, in particular, result in repeated releases of pathogens. As tropical forests and other ecosystems rich in biodiversity are being subject to increasing damage, hidden reservoirs of unknown pathogens are exposed; displaced wild animals bring the pathogens to humans; birds that hitherto had been separated are now meeting, with the likelihood of new viruses developing. Another critical reservoir is the Arctic permafrost. As it thaws, a variety of pathogens emerge from long hibernation; the infection of members of the Siberian Nenets indigenous community from an unearthed reindeer carcass is a warning shot. Some of the pathogens to come could well be still more unpleasant than Covid-19 - children will not always be spared, as the Nenets discovered.

Global warming and virus spillovers from animals to humans are tightly connected to food production. As concluded by the UN Food and Agriculture Organization (FAO) in April 2019, in State of the World's Biodiversity for Food and Agriculture (FAO, 2019, p. xxxviii), "key ecosystems that deliver numerous services essential to food and agriculture are declining rapidly", and as climate change moves relentlessly, the world's food supply is under severe threat. It does not help that, while 3 billion people currently suffer from land degradation, yet more fertile soil is being lost at a rate of 24 billion tonnes a year worldwide. We risk being confronted with both significantly decreased food availability and significantly increased population.

All components of natural capital - biodiversity, air, water, soil, climate - are crumbling under human pressures. Under such extreme threats, many might give up. However, the contributors to this book have embraced the spirit of the Prins van Oranje, who said (in French) when the Netherlands, of which he was head of State, was invaded by mighty and brutal armies under King Felipe II of Spain: “Il n'est pas nécessaire d'espérer pour entreprendre ni de réussir pour persévérer" (One need not hope in order to undertake nor succeed in order to persevere). And they have gone further than bearing witness. They have also followed the inspiration of Bob Marley, "Get up, stand up, stand up for your rights". Who are they and what are their achievements?

\section{DEFENDERS}

They are community leaders, organizers of mass protests or of campaigns unveiling pollution, land grabs, deforestation. They are rangers, farmers, teachers, artists. They face land invaders, loggers, poachers, dam builders, mining operators, drug traffickers, corrupt public authorities, death squads. They live in and around the Amazon, Congo or Southeast Asia forests; in 
East and Central African savannahs; in various Indian states; in the islands of the Coral Triangle across the Philippines and Indonesia; in Central American villages; in the plains of Dakota, USA; in Queensland, Australia, and so on.

Every year they are murdered by the hundreds. Nevertheless, their numbers are growing. The Guardian newspaper, and in particular Jonathan Watts, who popularized the name Defenders, regularly publishes information about them.

\section{LITIGANTS}

They are also active in many places - Australia, Colombia, China, European Union, India, New Zealand, Philippines, South Africa, Uganda, United States, appealing in the courts of justice to show that public authorities are failing, both themselves and the generations to come, by neglecting the common natural capital, the climate in particular, or even by acting as accomplices of rogue firms or gangs responsible for far-reaching damages.

Some are rather young, as befits front-line victims of the looming disasters. In the US, 21 students aged 11 to 22, from ten different states, are suing the federal government over immediate and future damages due to climate change denial or negligence. Likewise, a group of 25 young people in Colombia filed a suit against the state for failing to stop deforestation in the Amazon basin; the Supreme Court ruled in their favour. And in 2017, then nine-year-old Ridhima Pandey challenged the federal government in India's Supreme Court.

A claim that has been brought against New Zealand's government illustrates the potential for Māori communities, in their capacity as traditional guardians of the natural environment, to bring claims against governments for failing to properly tackle environmental issues. Their action resonates far beyond New Zealand's frontiers.

\section{COMING GENERATIONS ON THE FRONT LINE}

Another student, Greta Thunberg from Sweden, at age 15 started a different type of action, not in courts but in schools. What is the point of children going to school if they have no future? What is the point of them learning sciences if people in positions of responsibility refuse to listen to scientists? Millions of students have taken part - on Fridays, hence the name of their movement Fridays For Future (FFF) - in school strikes for the climate, throughout 130 countries. The FFF leaders in several countries - Belgium, Germany, New Zealand, Nigeria, Uganda - reflect on their experiences here. Often, they find inspiration and support from a remarkable organization, 350.org, the founder of which William "Bill" McKibben describes the origins, the methods and the prospects. 
Students graduating from "elite" universities used to take plush jobs with bright futures in prosperous firms. For many among them that is no longer the case; they seek compatibility between professional prospects and deeply felt ecological concerns, to the point of making firms anxious about their capacity for recruiting the best candidates. For certain employers, particularly those with activities that are fundamentally detrimental to the environment and to the climate in particular, that capacity to compete for talent is seriously dented.

\section{ENTREPRENEURS}

They pioneer ways of producing, storing and consuming energy without killing life on earth and damaging the climate, and of devising and disseminating new materials to save resources. Of growing and producing safe food without wiping out biological diversity and polluting to death bodies of water and the soil itself. Of profitably managing forests and ocean resources without exhausting them. Of renovating cities to make them more resilient, more efficient, less destructive and more hospitable. Of particular significance is the role that visionary and determined social entrepreneurs, local and regional leaders, can play in bringing their communities forward on paths for ecological and economic transition.

\section{INVESTORS}

Aware of the climate risks, they rebalance their portfolios away from high carbon footprint (e.g., coal, oil, cement) towards assets positively associated with the transition to a decarbonized economy (e.g., renewable energy providers, producers of efficient materials). Pioneers such as the Wallace Global Fund and the Rockefeller Brothers Fund have kickstarted this movement for responsible investors, which, since 2014, has gained strong momentum. Major financial management companies, such as BlackRock and Allianz, have made strong climate commitments and so too have major banks, such as HSBC and Standard Chartered. We will, of course, find out about delivery. Increasingly, investors are recognizing that it is the dirty activities of the last century that are risky and in decline, and that it is the clean investments of the twenty-first century that are likely to prosper.

When an investor has rebalanced her portfolio in this way, she is motivated to support those public policies that enhance the value of her new investments - for example, stricter carbon pricing policies. In this sense, private interests and natural capital-friendly public policies might come to converge.

So-called green bonds, and other instruments for financing transition-oriented activities, are emitted and traded under various forms. Their scope is fast growing, particularly in China and in the European Union. Their healthy devel- 
opment is conditional on the formulation and implementation of appropriate public policies and regulations, but their existence and expansion help drive such policies.

\section{COMMUNICATORS}

Effective communicators are vital in order to amplify and disseminate the messages from policy-makers and from scientists, all the more so as such messages are not easy to convey and as time is short. President Franklin Delano Roosevelt was able to explain and convince a majority to approve his policies, however unfamiliar these looked initially. Explaining how to shift to a more sustainable development path is no less vital than explaining how to exit from the Great Depression; it requires the same qualities of coherence, clarity and conviction.

In the fields of science and technology, Professor Richard Feynman was not only an outstanding pedagogue in his physics classes, he was also supremely able to guide non-specialists through seemingly impenetrable thickets of scientific and technical complexities. This he showed as a member of the Rogers Commission that was investigating the circumstances of the explosion of the space shuttle Challenger in 1986. After having properly reconfigured the chain of failures that led to the explosion, he pleaded effectively for more exacting remedies than the other members of the Commission and some NASA executives would have liked; he enlisted a public following nobody had anticipated. Like Roosevelt, he showed both an ability to relate to his fellow human beings and a strong sense of kindness. Richard Feynman embodied the perfect role model for today's scientists who are confronting scepticism, apathy and, increasingly, despair about the condition of the planet. Several among them, who have proved they are up to the task, explain here how that proves possible.

These are inspiring stories. However, do they have the potential to grow, to coalesce and to force a profound transformation in society and economy, in spite of formidable obstacles? In L'Ancien Régime et la Révolution, Livre III (1856), Alexis de Tocqueville shows how, in the second half of the eighteenth century, mushrooming new visions and actions converged to overthrow a 1000-year-old French Ancien Régime and generate a new order, despite seemingly insuperable obstacles. Nowadays we observe a similar pattern with the - still fragile - perspective of another, potentially broader, revolution. Time, however, is severely constrained.

Before laying down the actors' accounts - what the defenders, litigants, leaders of coming generations, entrepreneurs, investors, communicators, have to say - the first part of the book begins with a section gathering relevant, concise background papers in earth sciences, psychology, economics and politics. In Section 2, Costa Rica and Sweden, two countries that are more 
advanced on paths to ecological and economic transition deserve special presentations; so do the giants, China and the US, who are struggling in different ways with these issues. This first part of the book closes with an assessment of international cooperation and governance, with special reference to the Paris Agreement.

There are many truly outstanding people 'standing up for a sustainable planet' that are not included in the actors' accounts. Indeed many, such as David Attenborough and Jane Goodall, have been 'standing up' for still longer than any of the editors, authors or actors featured in this book, while at the same time inspiring and encouraging others to do the same, whether that be through high-profile documentary narration or community initiatives like the Jane Goodall Institute's TACARE and Roots \& Shoots programmes. This book showcases a multitude of individuals who have made exceptional contributions to the protection of our planet, but there are numerous others responsible for pioneering work across the globe that have paved the way for following generations of environmentalists: Davi Kopenawa, Wangari Maathai and Chandi Prasad Bhatt being outstanding examples.

\section{REFERENCES}

Childs, J.W. (2020), "Giant sequoias falling victim to climate change, study says", Weather.com, 23 January, accessed 8 August 2020 at https://weather.com/news/ news/2020-01-23-sequoias-dying-climate-change-drought-beetles.

Dosio, A., L. Mentaschi, E.M. Fischer and K. Wyser (2018), "Extreme heat waves under $1.5^{\circ} \mathrm{C}$ and $2{ }^{\circ} \mathrm{C}$ global warming", Environmental Research Letters, 13 (5), 054006 .

Food and Agriculture Organization (FAO) (2019), The State of the World's Biodiversity for Food and Agriculture, edited by J. Bélanger and D. Pillings, Rome: FAO Commission on Genetic Resources for Food and Agriculture Assessments.

Hofste, R.W., P. Reig and L. Schleifer (2019), "17 countries, home to one-quarter of the world's population, face extremely high water stress", WRI.org, 6 August [blog], accessed 8 August 2020 at https://www.wri.org/blog/2019/08/17-countries-home -one-quarter-world-population-face-extremely-high-water-stress.

Smith, A. (1776), An Inquiry Into the Nature and Causes of the Wealth of Nations, London: W. Strahan and T. Cadell, in the Strand.

Steffen, W., J. Rockström and K. Richardson et al. (2018), "Trajectories of the Earth System in the Anthropocene", Proceedings of the National Academy of Science, 115 (33), 8252-9.

Tocqueville, A. de (1856 [1866]), L'Ancien Régime et la Révolution, Livre III, 7th edition, Paris: Michel Lévy.

Warren, R., J. Price and E. Graham et al. (2018), "The projected effect on insects, vertebrates, and plants of limiting global warming to $1.5^{\circ} \mathrm{C}$ rather than $2^{\circ} \mathrm{C}$ ", Science, $\mathbf{3 6 0}$ (6390), 791-5.

Watts, N., M. Amann and N. Arnell et al. (2019), “The 2019 report of The Lancet Countdown on health and climate change: ensuring that the health of a child born today is not defined by a changing climate", 394 (10211), 1836-78, accessed 
8 August 2020 at https://www.thelancet.com/journals/lancet/article/PIIS0140 -6736(19)32596-6/fulltext.

$\mathrm{Xu}, \mathrm{C}$., T.A. Kohler and T.M. Lenton et al. (2020), "Future of the human climate niche", Proceedings of the National Academy of Sciences, 117 (21), 11350-55. 